\title{
Peningkatan Keahlian Identifikasi Peluang Usaha Bagi Calon Wirausaha di Kota Kendari
}

\author{
Gamsir $^{1}$, Ernawati*2, Tajuddin ${ }^{3}$, Ambo Wonua Nusantara ${ }^{4}$ \\ 1,2,3,4 Jurusan IESP, Fakultas Ekonomi dan Bisnis, Universitas Halu Oleo \\ *e-mail: ernawaty@uho.ac.id
}

\begin{abstract}
Covid-19 pandemic which has an impact on the economic slowdown encourages the importance of skill in identifying business opportunities for entrepreneurs. The community service program aims to increase the skills of potential entrepreneurs in Kendari City in identifying business opportunities during the Covid-19 pandemic. The activity was carried out through online learning for one month, starting from 12 June to 13 July 2020 with 30 participants (potential entrepreneurs). The stages of online learning were done in 3 sessions. The results of the program showed that participants experienced an increase in understanding and interest from before and after the implementation of the program for all indicators, namely: confidence in the ability to become an entrepreneur, views on the entrepreneurial profession, interest in becoming entrepreneurs, views on risks and opportunities during the pandemic. Participants assume that if they have a business during a pandemic, they will be able to survive. Participants also believe that business is not dependent on capital. Participants believe that they will be very capable of dealing with the business obstacles. Online learning activities that are carried out are very effective, which is shown by the perception of potential entrepreneurs who are able to identify opportunities during the pandemic, as well as the objectives of the community service program.
\end{abstract}

Keywords: identification, opportunity, online, entrepreneurship

\section{Abstrak}

Pandemi Covid-19 yang berdampak pada lesunya perekonomian semakin mendorong pentingnya keahlian mengidentifikasi peluang usaha bagi wirausaha. Program pengabdian masyarakat bertujuan untuk meningkakan keahlian calon wirausaha di Kota kendari dalam mengidentifikasi peluang usaha pada masa pandemi Covid-19. Kegiatan dilaksanakan melalui pembelajaran daring selama 1 bulan mulai 12 Juni-13 Juli 2020 dengan 30 peserta (calon wirausaha). Tahapan pembelajaran daring dilakukan sebanyak 3 sesi. Hasil kegiatan menunjukkan bahwa peserta mengalami peningkatan pemahaman dan minat dari sebelum dan setelah pelaksanaan program untuk seluruh indikator, yaitu: keyakinan akan kemampuan menjadi seorang wirausaha, pandangan tentang profesi wirausaha, minat menjadi wirausaha, pandangan tentang risiko dan peluang di masa pandemi. Peserta beranggapan bahwa jika memiliki usaha pada masa pandemi akan mampu bertahan. Peserta juga meyakini bahwa bisnis yang tidak tergantung pada modal. Peserta meyakini akan sangat mampu menangani kendala usaha yang dihadapi. Kegiatan pembelajaran daring yang dilaksanakan sangat efektif, yang ditunjukkan dengan persepsi calon wirausaha yang mampu mengidentifikasi peluang di masa pandemi, sebagaimana tujuan dari program pengabdian masyarakat.

Kata kunci: identifikasi, peluang, daring, wirausaha

\section{PENDAHULUAN}

Kasus Coronavirus Disease (Covid -19) hingga akhir Mei 2020 berdasarkan data Hopkins (2020) dilaporkan telah menginfeksi 6.343 .403 jiwa di seluruh dunia. Pada tanggal tersebut juga covid telah menginfeksi setidaknya 26.473 jiwa dengan 7.208 sembuh dan 1.613 meninggal di Indonesia. Penyebaran Covid-19 berdampak pada tidak saja dari aspek kehidupan namun juga ekonomi, terlebih bagi daerah yang menerapkan pembatasan sosial.

Pandemi covid-19 membawa Indonesia bahkan dunia ke ambang resesi, banyak negara yang memprediksi pertumbuhan ekonominya akan terdegradasi pada angka minus. Data BPS (2020) menunjukkan bahwa pertumbuhan ekonomi Indonesia triwulan I-2020 terhadap triwulan I-2019 tumbuh sebesar 2,97 persen (y-on-y) atau melambat dibanding capaian 
triwulan I-2019 sebesar 5,07 persen. Bahkan ekonomi Indonesia triwulan I-2020 terhadap triwulan sebelumnya mengalami kontraksi sebesar 2,41 persen (q-to-q). Dari sisi produksi, penurunan disebabkan oleh kontraksi yang terjadi pada beberapa lapangan usaha. Dari sisi pengeluaran, penurunan disebabkan oleh kontraksi pada seluruh komponen pengeluaran.

Krisis akibat covid-19 ini tidak saja berdampak kepada usaha skala besar, namun juga skala kecil. Pada tahun 1998 dan 2008 beberapa usaha berskala besar mengalami penurunan bahkan tidak sedikit yang tumbang akibat mahalnya biaya produksi. Krisis saat ini lebih dahsyat dari krisis sebelumnya dampaknya bukan hanya kepada Usaha Besar namun juga terhadap Usaha Mikro, Kecil, dan Menengah (UMKM). Selain pengusaha, angkatan kerja baru khusunya yang lulus dari perguruan tinggi merupakan komponen masyarakat yang turut serta menderita karena pandemi covid. Pada saat mereka antri untuk mendapatkan pekerjaan pada sektor formal namun sebaliknya fenomena pemutusan hubungan kerja dan karyawan yang di rumahkan menjadi berita yang mengisi bacaan dan tontonan harian mereka.

Bagi angkatan kerja baru khususnya lulusan perguruan tinggi, terdapat beberapa masalah yang dihadapi, yaitu: (1). Kebijakan semi lockdown dan pembatasan sosial berskala besar (PSBB) mengurangi aksesibilitas masayarakat yang berdampak pada penurunan daya beli dan omzet perusahaan yang secara jangka panjang menjadi tantangan bagi penciptaan lapangan kerja baru, (2) penurunan pertumbuhan ekonomi global pasca pandemi menyebabkan perekonomian seakan kembali ke tahap pra kondisi. Situasi ini memerlukan waktu yang cukup lama sehingga akan berdampak pada lesunya penciptaan kesempatan kerja; dan (3) penyerapan tenga kerja baru masih didominasi oleh tenaga kerja yang berpendidikan ke SD ke bawah. Calon wirausaha tidak memiliki skill dan semangat berwirausaha.

Salah satu solusi yang ditawarkan untuk mengatasi masalah di atas adalah para lulusan perguruan tinggi harus mau dan siap menjadi wirausaha baru yang dapat memanfaatkan berbagai peluang. Sehingga perguruan tinggi sangat penting untuk mengambil bagian dalam mengedukasi mahasiswa dan lulusannya, terlebih bagi mereka yang bukan berasal dari program studi yang memiliki konten pembelajaran kewirausahaan. Universitas Halu Oleo melalui program KKN Tematik telah melakukan langkah-langkah penting dalam menghadapi masa pandemi. Pada tahun 2020, Universitas Halu Oleo melaksanakan kegiatan pengabdian masyarakat sebanyak 125 judul yang bertemakan pandemi Covid. Kegiatan ini mengikuti protokol keseharan (prokes) yang ketat. Kegiatan pengabdian yang tidak terkait dengan praktik, dilakukan secara daring. Begitupun halnya dengan program peningkatan keahlian identifikasi usaha bagi calon wirausaha ini dilaksakan melalui daring (webinar). Beberapa studi sebelumnya mengkaji efektifitas pelatihan terhadap minat menjadi wira usaha seperti studi Sugiarto, Wismanto, \& Utami (2015); Mustapha \& Selvaraju (2015); Rahmi \& Hidayati (2019); Lestari \& Wijaya (2012); dan Suarjana \& Wahyuni (2017) yang menunjukkan bahwa pelatihan kewirausahaan akan meningkatkan minat wira usaha. Namun pelatihan kewirausahaan yang dikaji pada stusi tersebut menggunakan metode tatap muka, berbeda halnya dengan kegiatan pengabdian masyarakat ini yang dilakukan via daring. Dengan demikian kiranya penting untuk mengkaji bagaimana peningkatan keahlian identifikasi peluang calon wira usaha melalui program pembelajaran daring.

\section{METODE}

Pelaksanaan KKN tematik 2020 diawali dengan indentifikasi calon peserta. Rekruitmen peserta dilakukan dengan menyebar kuisioner bagi calon wirausaha. Penentuan peserta webinar ditentukan dengan melihat total skor indikator yang bernilai sangat baik, dengan beberapa syarat lainnya yaitu: (1) memiliki perangkat HP/Laptop dan (2) bersedia mengikuti seluruh tahapan pelatihan. Berdasarkan evaluasi dari 35 calon peserta, maka diperoleh 30 peserta pembelajaran daring. Kegiatan KKN Tematik ini dilaksanakan di Kota kendari, tanggal 12 Juni -13 Juli 2020. Metode pelaksanaan kegiatan dilakukan dengan full daring, melalui 
platform zoom. Materi yang diberikan melalui tiga tahapan: (1). tantangan bagi angkatan kerja baru: sekarang dan akan datang, (2) prasyarat bagi calon wirausaha untuk menjadi pengusaha yang handal, dan (3) teknik mengidentifikasi peluang usaha masa pandemi dan sesudahnya. Penyaji materi bersumber dari pihak akademisi dan praktisi.

Indikator keberhasilan program diukur dengan membandingkan kuisioner sebelum (pre test) dan setelah (post test) kegiatan dilaksanakan. Namun beberapa pertanyaan yang belum disajikan saat pre test juga diberikan saat post test. Pertanyaan yang diberikan menggunakan skala likert (1-5). Adapun untuk menghitung rata-rata nilai dari peserta pada setiap indikator digunakan rumus sebagaimana persamaan 1 dan 2.

$$
\begin{aligned}
& \text { Skor rata }- \text { rata }=\frac{\sum_{i=1}^{n} X i}{n} \text {. } \\
& \operatorname{dalam}(\%)=\frac{\sum_{i=1}^{n} X i}{(n \times \text { skor maksimum })} \times 100
\end{aligned}
$$

Pada sisi lain, efektifitas kegiatan yang ditunjukkan dengan kemampuan identifikasi usaha pada masa pandemi dikatakan berhasil jika berada pada kategori efektif dan atau sangat efektif, dengan tingkatan kategori sebagai berikut:

Tabel 1. Efektifitas Kegiatan

\begin{tabular}{ll}
\hline Interval (dalam persen) & Kategori \\
\hline Lebih besar dari 80 & Sangat Efektif \\
$61-80$ & Efektif \\
$41-60$ & Cukup Efektif \\
$21-40$ & Tidak Efektif \\
$\leq 20$ & Sangat Tidak Efektif \\
\hline
\end{tabular}

\section{HASIL DAN PEMBAHASAN}

Kegiatan pembelajaran daring dilaksanakan dalam 3 tahapan sebagaimana Tabel 2. Pada tahap pertama (Sesi 1), peserta diberikan gambaran mengenai tantangan dan persaingan yang akan dihadapinya dalam dunia kerja sehingga diharapkan akan merubah mindset dari pencari kerja menjadi pencipta lapangan kerja. Pemateri yang dihadirkan pada sesi ini berasal dari akademisi bidang ketenagakerjaan, yaitu: Bapak Prof. Dr. H. Muhammad, Syarif, S.E.,M.S. Setelah diberikan pemahaman mengenai pentingnya menciptakan peluang atau berwira usaha, pada tahap selanjutnya (Sesi 2) peserta kemudian diberikan pemahaman mengenai prasyarat menjadi wirausaha dan atau mental yang perlu dimiliki oleh seorang wirausaha, khusunya cara berfikir bahwa modal bukanlah satu-satunya faktor menjadi wirausaha handal. Peserta juga dimotivasi agar berani menjadi wirausaha. Adapun pemateri pada sesi ini yaitu parktisi usaha yang juga merupakan Ketua Forum IKM/UKM Sulawesi Tenggara yaitu Bapak H. Abdul Hakim, S.E.,M.S.

Pada tahap akhir (Sesi 3), peserta diberikan pemahaman mengenai bagaimana mengidentifikasi peluang usaha pada masa pandemi, dengan pemateri Ibu Hajar, S.Ag yang merupakan salah satu IKM produk olahan pangan lokal terbaik Provinsi Sulawesi Tenggara. Sehingga berbekal mental wirausaha, dan pemahaman mengidentifikasi peluang, diharapkan peserta pelatihan siap menjadi seorang wirausaha handal.

Kegiatan Sesi 1 dengan materi tantangan bagi angkatan kerja baru: kini dan akan datang yang menghadirkan pemateri dari pihak akademisi menyajikan profil angkatan kerja di Indonesia umumnya dan Provinsi Sulawesi Tenggara khususnya. Pada sesi ini juga dipaparkan ketatnya persaingan dalam dunia pencari kerja, sehingga lulusan perguruan tinggi tidak boleh 
hanya mengandalkan pekerjaan sebagai pegawai tetap, apalagi Aparatur Sipil Negara. Pemateri juga memaparkan beberapa bisnis dan keahlian yang dibutuhkan di era digital.

Tabel 2. Tahapan Pelaksanaan Kegiatan

\begin{tabular}{rlcc}
\hline No & Tema Kegiatan & Waktu & Pemateri \\
\hline 1 & $\begin{array}{l}\text { Tantangan angkatan kerja baru: kini } \\
\text { dan akan datang }\end{array}$ & 27 Juni 2020 & Akademisi \\
\hline 2 & $\begin{array}{l}\text { Prasyarat menjadi wirausaha yang } \\
\text { tangguh }\end{array}$ & 4 Juli 2020 & Praktisi \\
\hline 3 & Identifikasi peluang usaha & 11 Juli 2020 & Praktisi
\end{tabular}

Sumber: Program KKN Tematik, 2020

Hasil evaluasi dari kegiatan ini menunjukkan bahwa 86,0 persen peserta berminat menjadi entrepreneur, atau berada pada kategori sangat berminat. Skor ini meningkat dari sebelum mengikuti kegiatan sebesar 83,3 persen. Dengan dmikian kegiatan ini dianggap berhasil meningkatkan minat calon wira usaha. Berdasarkan hasil penelitian Putra (2012) salah satu faktor yang menentukan minat wira usaha adalah visi (mindset). Hasil program ini juga konsisten dengan studi sebelumnya Sugiarto, Wismanto, \& Utami (2015); Mustapha \& Selvaraju (2015); Rahmi \& Hidayati (2019); Lestari \& Wijaya (2012); dan Suarjana \& Wahyuni (2017) meskipun menggunakan metode pembelajaran yang berbeda.

Kegiatan Sesi 2 yang bertemakan prasyarat menjadi wirausaha yang tangguh dengan menghadirkan penyaji Ketua Forum UKM-IKM Sulawesi Tenggara dimaksudkan untuk memberi penguatan kepada peserta bahwa semua bisa menjadi wirausaha, namun harus memiliki keberanian untuk memulai walaupun dari nol. Penyaji juga memaparkan bahwa musuh utama berwirausaha adalah diri kita sendiri. Seorang wirausaha harus berfikir sederhana, jangan mengatakan tidak bisa /tidak mungkin, harus berpikir 'kepepet', darurat, minoritas; berani tampil beda dan unik. Pada sisi lain, pola pikir wirausaha diantaranya: berpikir risiko dulu, bukan untungnya; harus berani mengambil risiko dalam skenario terburuk; urusan administrasi bukan menjadi fokus utama yang penting bisnis dapat berjalan dahulu; harus sabar (memperbesar bisnisnya dulu, baru untuk kepentingan pribadi); pandai melihat peluang /opportunity dan segera lakukan aksi, jangan menunda-nunda. Calon wira usaha harus berpikir sebagai pemenang dimana pemenang selalu melihat peluang dalam setiap masalah, bukan melihat masalah dalam setiap peluang. Untuk memulai menjadi wirausaha, pemeteri memaparkan tips: mulailah dari hal-hal kecil /sepele; harus fokus, tidak boleh dibuat sampingan; produk yang spesifik, sulit ditiru/unik; berorientasi pasar dahulu, kemudian produksi dan outsourcing; perbanyak jaringan terkait dengan bisnis yang akan dilakukan; carilah peluang dan waktu yang tepat untuk memulai dan mengembangkan bisnis. Penguatan juga diberikan kepada peserta bahwa modal bukan faktor utama dalam berwirausaha tetapi trust. Pandangan pemateri ini berbeda dengan hasil penelitian Srihadiastuti \& Hidayatullah (2018) yang menunjukkan bahwa faktor utama penyebab kegagalan usaha baru para lulusan adalah kendala pada permodalan, karena kendala pada permodalan menyebabkan kendala- kendala pada faktor lainnya.

Hasil evaluasi kegiatan Sesi 2 sebagaimana disajikan pada Tabel 3 menunjukkan bahwa peserta mengalami peningkatan pemahaman dari sebelum pelatihan dan setelah pelatihan, dari beberapa indikator: keyakinan akan kemampuan mejadi seorang wirausaha, pandangan tentang profesi wirausaha sebagai profesi yang menyenangkan, dan pandangan tentang risiko. Bahkan untuk aspek pandangan tentang risiko, grade peserta pelatihan meningkat dari yang semula menganggap bahwa risiko dalam usaha merupakan suatu yang menantang, menjadi sangat menantang. 
Tabel 3. Indikator Keberhasilan Kegiatan Tahap 2

\begin{tabular}{lrrrrr}
\hline \multirow{2}{*}{ Indikator } & \multicolumn{2}{c}{ Sebelum } & \multicolumn{3}{c}{ Setelah } \\
\cline { 2 - 6 } & Skor rata-rata & $\%$ & Skor & Rata-rata & $\%$ \\
\hline Kemampuan Menjalani Profesi & 3,2 & 64,7 & 3,5 & 70,0 \\
\hline Entrepreneur & 4,2 & 83,3 & 4,4 & 88,7 \\
\hline Persepsi tentang entrepreneur & 3,9 & 77,3 & & 4,3 & 85,3 \\
\hline Pandangan tentang Risiko & & & & 4,1 & 81,3 \\
\hline Entrepreneur Tidak tergantung pada modal & & & & 4,2 & 84,0 \\
\hline Berani menjadi Entrepreneur & & & &
\end{tabular}

Sumber: Hasil pelaksanaan Kegiatan 2020

Calon wirausaha juga telah meyakini bahwa bisnis yang akan dijalankan tidak tergantung pada modal, dengan skor 81,3 persen atau berada pada kategori sangat setuju. Hasil penelitian Halim, Aziz, \& Firmanzah (2014) menunjukkan bahwa perusahaan yang sukses mempertahankan usahanya selain kerjasama dengan pemilik modal, juga memiliki jaringan usaha, semangat diri, juga pengalaman sebagai karyawan. Bahkan hasil penelitian Wartika (2015) menunjukkan bahwa faktor dominan yang mempengaruhi kegagalan mahasiswa wirausaha yaitu faktor tidak kompeten dalam manajerial, disusul faktor pengalaman, dan kemudian barulah faktor keuangan pada posisi selanjutnya. Peserta pelatihan yakin akan berani menjadi seorang wirausaha dengan skor 84,0 persen atau berada pada kategori sangat berani. Keberanian wirausaha dalam berbisnis bukan hanya berani membuka usaha, namun juga berani gagal, berani mencoba, dan berani bermimpi (Sunarya, Sudaryono, \& Saefullah, 2011). Dengan demikian peserta pelatihan telah memiliki indikator sebagaimana pandangan Suryana (2014) yang mengemukakan bahwa indikator kewirausahaan terdiri dari: percaya diri, berorientasi hasil, berani tampil beda dan tangguh dalam bertindak, serta berani mengambil risiko dengan penuh perhitungan dan oleh karena itu menyukai tantangan,

Kegiatan Sesi 3 yang bertemakan identifikasi peluang usaha dilakukan pada tahapan akhir kegiatan. Pada tahap ini pemateri memaparkan bahwa untuk memulai usaha dengan modal minim, beberapa langkah yang harus dilakukan yaitu: memilih Jenis usaha yang paling diminati sesuai dengan skill, melakukan riset pasar, menghitung modal yang harus dikeluarkan, melakukan penghematan biaya operasional, menggunkan peralatan yang masih layak pakai dan tempat usaha dekat dengan target pasar. Menghadapi covid, beberapa langkah yang perlu dilakukan IKM yaitu: memberi diskon, pemasaran online, dalam kota free ongkos kirim, dan aktif mengikuti seminar online dan jaringan usaha agar mengetahui peluang-peluang yang ada. Hasil evaluasi kegiatan Sesi 3 ini sebagaimana disajikan pada Tabel 4 menunjukkan bahwa peserta mengalami peningkatan dalam hal pandangan tentang peluang di masa pandemi meskipun masih dalam pada grade yang sama yang sebelumnya memiliki skor 70 persen menjadi 78 persen. Peningkatan ini juga sejalan dengan keyakinan calon wirausaha yang beranggapan bahwa jika ia memiliki usaha pada masa pandemi akan mampu bertahan yang semula memiliki skor 70,6 persen menjadi 78,6 persen. Peserta juga meyakini akan kemampuannya menangani kendala usaha dimasa pandemi dengan keyakinan rata-rata 82,7 persen. Zimmerer \& Scarborough (2008) mengemukakan bahwa kewirausahaan tidak sama seperti melempar anak panah dan berharap untuk mendapatkan yang terbaik, namun kewirausahaan memiliki banyak kendala yang harus dihadapi oleh wirausahawan.

Pada sisi lain, pesert memiliki keyakinan akan kemampuannya mengidentifikasi peluang usaha pada masa pandemi sebesar 84 persen atau berada pada kategori sangat mampu. Zimmerer dan Scarborough (2008) menggambarkan entrepreneur sebagai seseorang yang menciptakan usaha baru dengan menghadapi ketidakpastian dan risiko melalui pengidentifikasian peluang yang signifikan dan penggunaan sumber daya yang diperlukan. 
Pandangan tersebut sejalan dengan Saiman (2014) yang mengemukakan bahwa fungsi wirausaha yaitu selain menciptakan nilai tambah dan usaha baru, juga menanggung risiko dan ketidakpastian, mengombinasikan peluang peluang ke dalam cara yang baru dan berbeda, serta membuka peluang-peluang baru. Adapun kegiatan yang telah dilakukan dalam tiga tahapan telah sesuai dengan pandangan tersebut, dimana peserta pelatihan memiliki keyakinan sangat mampu untuk mengidentifikasi peluang di masa pandemi, sehingga program KKN Tematik sebagaimana judul program: Peningkatan keahlian indentifikasi peluang usaha di masa pandemi bagi calon wirausaha melalui pembelajaran daring telah berhasil dan atau efektif.

Tabel 4. Indikator Keberhasilan Kegiatan Tahap 3

\begin{tabular}{lrrrrr}
\hline & \multicolumn{1}{l}{ Sebelum } & \multicolumn{3}{l}{ Setelah } \\
\cline { 2 - 7 } Indikator & Skor rata-rata & $\%$ & Skor & Rata-rata & \multicolumn{2}{l}{$\%$} \\
\hline Peluang Masa Pandemi & 3,5 & 70,0 & 3,9 & 78,0 \\
\hline $\begin{array}{l}\text { Pandangan tentang kemampuan } \\
\text { usaha bertahan dimasa pandemi }\end{array}$ & 3,5 & 70,6 & & 3,9 & 78,6 \\
\hline Mampu Menagani kendala & & & & 4,1 & 82,7 \\
\hline Mampu Mengidentifikasi Peluang Masa pandemi & & & 4,2 & 84,0 \\
\hline
\end{tabular}

Sumber: Hasil pelaksanaan Kegiatan 2020

Pada sisi lain, kegiatan sosialisasi yang dilaksanakan dengan daring menghadapi beberapa kendala teknis akibat ketidakstabilan jaringan, dan beberapa gangguan teknis lainnya. Untuk menangani tidak tersampaikannya seluruh materi, maka peserta pelatihan diberikan file materi atau tutorial yang ada. Pemberian materi lengkap akan mendorong peserta pelatihan dapat belajar dan mengulanginya sendiri maupun berkelompok tentang materi yang telah disampaikan (Desnelita dkk., 2019).

\section{KESIMPULAN}

Kegiatan pembelajaran daring yang dilaksanakan dalam 3 tahapan telah mampu meningkatkan pemahaman peserta dalam mengidentifikasi peluang usaha pada masa pandemi. Pada tahap pertama, peserta diberikan gambaran mengenai tantangan dan persaingan yang akan dihadapinya dalam dunia kerja sehingga membuka wawasan berfikir bahwa peluang kerja harus diciptakan bukan dicari. Hasil kegiatan ini menunjukkan bahwa 86,0 persen peserta berminat menjadi entrepreneur, atau berada pada kategori sangat berminat. Skor ini meningkat dari sebelum mengikuti webinar sebesar 83,3 persen. Pada tahap 2 materi yang diberikan berupa prasyarat wirausaha handal. Peserta webinar mengalami peningkatan pemahaman dan minat dari sebelum dan setelah kegiatan, dari beberapa indikator: keyakinan akan kemampuan mejadi seorang wirausaha, pandangan tentang profesi wirausaha sebagai profesi yang menyenangkan, dan pandangan tentang risiko. Calon wirausaha telah meyakini bahwa bisnis yang akan dijalankan tidak tergantung pada modal dan telah memiliki keberanian (sangat berani) menjadi seorang wirausaha. Pada tahap akhir, peserta diberi tips mengidentifikasi peluang usaha pada masa pandemi. Pelatihan yang dilaksanakan sangat efektif yang ditunjukkan dengan persepsi calon wirausaha yang sangat mampu mengidentifikasi peluang di masa pandemi, sebagaimana tujuan dari program KKN Tematik.

Pada sisi lain, beberapa saran yang diajukan yaitu: (1) bagi pelaksana kegiatan pelatihan kewirausahaan khususnya bagi calon wirausaha diharapkan dilakukan melalui beberapa tahapan dalam pelaksanaannya, dengan membuka wawasan berfikir/mindset terlebih dahulu, kemudian motivasi wirausaha, dan terakhir skill teknis lainnya; dan (2) pelatihan secara online memiliki beberapa keterbatasan, untuk menutupi keterbatasan tersebut, peserta pelatihan perlu diberikan materi dan video yang dapat mereka akses secara mandiri. 


\section{UCAPAN TERIMA KASIH}

Penulis mengucapkan terimakasih kepada Pimpinan Universitas Halu oleo dan Ikatan Sarjana Ekonomi Indonesia (ISEI) Cabang Kendari.

\section{DAFTAR PUSTAKA}

BPS. (2020). Berita Resmi Statistik No. 39/05/Th. XXIII, 5 Mei 2020 tentang Pertumbuhan Ekonomi Indonesia Triwulan I-2020. Badan Pusat Statistik. Retrieved Mei 7, 2020 from https://www.bps.go.id.

Desnelita, Y., Gustientiedina, G., Susanti, W., Nasien, D., \& Noratama Putri, R. (2019). PKMS Pelatihan Desain Grafis Menuju Wirausaha Bagi Pemuda RT.03 RW.04 Kelurahan Umban Sari. Dinamisia: Jurnal Pengabdian Kepada Masyarakat. 3(2), 266-272. https://doi.org/10.31849/dinamisia.v3i2.3662.

Halim, R.E., Aziz, A., \& Firmanzah. (2014). Faktor Kunci Sukses Perusahaan Kecil Dan Menengah Dalam Menghindari Kegagalan Dalam Periode Lima Tahun Pertama. Jurnal Pengkajian Koperasi dan UKM. 9, 71-84.

Hopkins, Johns. (2020). Coronavirus Worldwide Graphs. Johns Hopkins Coronavirus Resource Center. Retrieved Mei 10, 2020 from https://www.worldometers.

Lestari, R.B., \& Wijaya,T. (2012). Pengaruh Pendidikan Kewirausahaan terhadap Minat Berwirausaha Mahasiswa di STIE MDP, STMIK MDP, dan STIE MUSI. Forum Bisnis dan Kewirausahaan Jurnal Ilmiah STIE MDP. 1(2), 112-119.

Mustapha, M. \& Selvaraju, M. (2015). Personal Attributes, Family Influences, Entrepreneurship Education and Entrepreneurship Inclination Among University Students. Kajian Malaysia. 33(1), 155-172.

Putra, Rano Aditia. (2012. Faktor-Faktor Penentu Minat Mahasiswa manajemen Untuk Berwirausaha (Studi Mahasiswa Manajemen Fakulta Ekonomi Universitas negeri padang). Jurnal Manajemen. 1(1), 1-15.

Rahmi, V.A \& Hidayati, R.A. (2019). Efektivitas Pelatihan Keterampilan Dalam Menumbuhkan Minat Wirausaha Wanita Melalui Motivasi Diri Berwirausaha. JMK (Jurnal Manajemen dan Kewirausahaan), 4(1), 1-16 doi:http://dx.doi.org/10.32503/jmk.v4i1.350

Saiman, Leonardus. (2014). Kewirausahaan: Teori, Praktik, dan Kasus-kasus. Jakarta: Salemba Empat.

Srihadiastuti, R. \& Hidayatullah, D.S. (2018). Analisis Penyebab Kegagalan Mendirikan Usaha Baru Pada Para Lulusan Program Wirausaha Baru Jawa Barat Kelas Ide Bisnis. Jurnal Ekonomi Pendidikan dan Kewirausahaan. 6(1), 31-44, DOI: 10.26740/jepk.v6n1.p31-44.

Suarjana, A.A.G.M. \& Wahyuni, L.M. (2017). Faktor Penentu Minat Berwirausaha Mahasiswa (Suatu Evaluasi Pembelajaran), Jurnal Bisnis dan Kewirausahaan. 13(1), 11-22.

Sugiartom J., Wismanto, Y. B., \& Utami, C.T. (2015). Efektivitas Pelatihan Entrepreneurship Skill Untuk Meningkatkan Minat Menjadi Entrepreneur. Prediksi Kajian Ilmiah Psikologi. 4(1), 51 $-60$.

Sunarya, P.O.A., Sudaryono, \& Saefullah, A. (2011). Kewirausahaan Membahas: Pengelolaan dan Pengembangan Entrepreneurship IT-Preneurship, Kewirausahaan di Bidang Teknologi Informasi Teori dan Praktik Pengelolaan Kewirausahaan Dilengkapi dengan Kasus. Yogyakarta: ANDI.

Suryana. (2014). Kewirausahaan: Kiat dan Proses Menuju Sukses. Jakarta: Salemba Empat.

Wartika, I Wayan. (2015). Analisis Faktor Penyebab Kegagalan Usaha Penerima Program Mahasiswa Wirausaha (PMW) di Universitas Pendidikan Ganesha Tahun 2013. Jurnal Pendidikan Ekonomi, Ekuitas. 3(1), 41-51.

Zimmerer, T.W., \& Scarborough, N.M. (2008). Essentials of Entrepreneurship and Small Business Management. New Jersey: Prentice Hall. 